\title{
Phytobiological-facilitated Production of Silver Nanoparticles From Selected Non-cultivated Vegetables in Nigeria and Their Biological Potential
}

\section{Nijerya'da İşlenmemiş Sebzelerden Fitobiyolojikler ile Kolaylaştırılmış Gümüş Nanopartiküllerinin Üretimi ve Biyolojik Potansiyelleri}

\author{
(D) Oluwasesan M. BELLO1*, (D) Olubunmi Stephen OGUNTOYE1, (D) Adewumi Oluwasogo DADA², (D) Oluwatoyin E. BELLO³, (D) Tijjani ALI4, \\ (D) Ahmad Abdullahi ALHAJI4 (D) Oluwatosin ADENIYI4 \\ 1 University of Ilorin, Department of Chemistry, Ilorin, Kwara State, Nigeria \\ ZUniversity of Ilorin, Department of Crop Protection, Ilorin, Kwara State, Nigeria \\ 3Landmark University Nanotechnology Laboratory, Department of Physical Sciences, Industrial Chemistry Programme, Omu Aran, Kwara State, Nigeria \\ 4Federal University Dutsin-Ma, Department of Applied Chemistry, Dutsin-Ma, Katsina State, Nigeria
}

\begin{abstract}
Objectives: Plant-mediated synthesis [silver (Ag) to form Ag nanoparticles (AgNPs)] is becoming progressively well accepted in many scientific and pharmaceutical fields. The aim of this study was to synthesize AgNPs using air-dried leaves of four neglected vegetables, i.e. Ceratotheca sesamoides, Ceiba pentandra, Crassocephalum crepidioides, and Launaea taraxacifolia.

Materials and Methods: Ultraviolet-visible (UV-Vis) spectroscopy, fourier transform infrared (FTIR) spectroscopy, and scanning electron microscopy (SEM) were used for characterization. Cell stabilization membrane and lipoxidase assays were used to determine used to assess the antiinflammatory activities while 2,2-diphenyl-1-picryl-hydrazyl-hydrate (DPPH) and 2,2'-azinobis(3-ethylbenzothiazoline-6-sulfonic acid (ABTS+) assays were used to assess the antioxidant activities of AgNPs [L. taraxacifolia-AgNPs, C. sesamoides Ag nanoparticles (CS-AgNPs), C. pentandra Ag nanoparticles (CP-AgNPs), and C. crepidioides AgNPs (CC-AgNPs)].

Results: The UV-Vis spectra of the synthesized NPs displayed absorption bands at around 360-440 nm, which is a characteristic band for AgNPs. The SEM image showed that the AgNPs formed were spherical in morphology. CC-AgNPs exhibited the most significant inhibitory activity against human red blood cell membrane stabilizasyonu [median inhibitory concentration $\left(\mathrm{IC}_{50}\right): 32.2 \mathrm{\mu g} / \mathrm{mL}$ ] while CS-AgNPs displayed the most significant inhibitory activity against lipoxygenases $\left(\mathrm{IC}_{50}: 32.8 \mu \mathrm{g} / \mathrm{mL}\right.$ ). CP-AgNPs exhibited the most significant antioxidant effect against both ABTS and DPPH $\left(\mathrm{IC}_{50}: 5.5\right.$ and $\left.6.4 \mu \mathrm{g} / \mathrm{mL}\right)$ when compared to ascorbic acid $\left(\mathrm{IC}_{50}: 4.7 \mu \mathrm{g} / \mathrm{mL}\right)$.

Conclusion: The synthesized AgNPs were found to be stable and the FTIR evidence suggested that the phytochemicals in the vegetables might have played an important role in the reduction and stabilization of AgNPs. This work showed that the synthesized AgNPs from non-cultivated vegetables can find relevance and application in health, drugs, food and environmental science. The evidences herein further confirmed their ethnopharmacological applications.
\end{abstract}

Key words: AgNPs, antiinflammatory, antioxidant, non-cultivated vegetables, nanoparticles

Öz

Amaç: Bitkiler aracılıklı sentez [gümüș nanopartikülleri (AgNP) oluşturmak için gümüş (Ag)] birçok bilimsel ve farmasötik alanda artan bir şekilde kabul görlmektedir. Bu çalıșmanın amacı havada kurutulmuş işlem görmemiş sebze (Ceratotheca sesamoides, Ceiba pentandra, Crassocephalum crepidioides ve Launaea taraxacifolia) yapraklarını kullanarak AgNP'lerinin sentezidir.

Gereç ve Yöntemler: Karakterizasyon için ultraviyole-görünür bölge (UV-Vis) spektroskopisi, fourier transforme kızılötesi (FTIR) spektroskopisi ve taramali elketron mikroskopisi (SEM) kullanılmıştır. AgNP'lerin [L. taraxacifolia-AgNP'ler, C. sesamoides Ag nanopartikülleri (CS-AgNPs), C. pentandra Ag nanopartikülleri (CP-AgNP) ve C. crepidioides Ag nanopartikülleri (CC-AgNP)] antienflamatuvar aktivitesini belirlemek için hücre stabilizasyon membranı ve lipoksidaz yöntemleri kullanılırken antioksidan aktivitelerini değerlendirmek için 2,2-difenil-1-pikrilhidrazil hidrat (DPPH) ve 2,2'-azinobis(3-etilbenzotiyazolin-6-sulfonik asit (ABTS+) yöntemleri için kullanılmıștır.

*Correspondence: E-mail: obello@fudutsinma.edu.ng, Phone: +2348062320327 ORCID-ID: orcid.org/0000-0003-1431-7319

Received: 06.06.2019, Accepted: 19.09.2019

OTurk J Pharm Sci, Published by Galenos Publishing House. 
Bulgular: Sentez edilen NP'lerin UV-Vis spektrumları AgNP'leri için karakteristik bir bant olan 360-440 nm arasında absorpsiyon bantları göstermiștir. SEM görüntüleri AgNP'lerin küresel morfolojilerinin olduğunu göstermiștir. CC-AgNP'ler insan kırmızı kan hücresi membrane stabilizasyonu [medyan inhibitor konsantrasyon $\left(\mathrm{IC}_{50}\right): 32,2 \mu \mathrm{g} / \mathrm{mL}$ ] için en yüksek inhibitor etkiyi gösterirken, CS-AgNP'leri lipoksijenazlara karşı en belirgin inhibitor etkiyi göstermiştir ( $\mathrm{IC}_{50}: 32,8 \mu \mathrm{g} / \mathrm{mL}$ ). CP-AgNP'leri hem ABTS+ hem de DPPH için $\left(\mathrm{IC}_{50}: 5,5 \mu \mathrm{g} / \mathrm{mL}\right.$ ve 6,4 $\left.\mu \mathrm{g} / \mathrm{mL}\right)$ askorbik asitle karşılaştırıldığında $\left(\mathrm{IC}_{50}: 4,7 \mu \mathrm{g} / \mathrm{mL}\right)$ en belirgin antioksidan etki göstermişlerdir.

Sonuç: Sentez edilen AgNP'ler stabil bulunmuştur ve FTIR verileri sebzelerdeki fitokimyasalların AgNP'lerin redüksiyonunda ve stablizasyonunda önemli rol oynadıklarını göstermiiştir. Bu çalışma ilenmemiş bitkilerden sentez edilen AgNP'lerin sağlık, ilaç, gıda ve çevresel bilimlerde ilgi ve uygulama alanı bulabileceğini göstermiștir. Buradaki bilgiler etenoparmakolojik uygulamalarını onaylamıştır.

Anahtar kelimeler: AgNP'ler, antienflamatuvar, antioksidan, işlem görmemiş sebzeler, nanopartiküller

\section{INTRODUCTION}

For centuries, cultures around the world have continuously employed and taken advantage of edible but non-cultivated plants for sufficient nutrition, food security, and wealth creation. ${ }^{1-3}$ These non-cultivated plants supply necessary and essential components of the human diet, supplying the body with various minerals, protein, and certain precursors of human hormones besides helping in the build-up of energy. ${ }^{4-6}$

Some of the plants studied here are non-cultivated due to their being tagged as "poor man's" vegetables but are eaten by the locals. Ceratotheca sesamoides ${ }^{7}$ belongs to the family Pedaliaceae. It is mostly found in Africa and it grows as a wild and non-cultivated plant. However, in some parts of Africa, it is being cultivated, and because of its similarities with common sesame (Sesamum indicum), some call it false sesame., Although widely regarded as a delicacy in most West African countries, literature on this plant and its consumption is scanty and not sufficient. ${ }^{10} \mathrm{C}$. sesamoides is traditionally employed in the management of diarrhea in Nigeria. The plant is used as an aphrodisiac and in the treatment of jaundice, snake bites, and skin ailments. C. sesamoides leaf infusions are used to facilitate delivery in both humans and animals. ${ }^{10-13}$ In northern Nigeria, $C$. sesamoides seeds are used to relieve circumcision pains.

Ceiba pentandra belongs to the family Malvaceae. ${ }^{7}$ It is native to the Caribbean, Central America, northern South America, Mexico, and tropical West Africa. Besides its young leaves' nutritional benefits, in Nigeria many locals use its leaves for treating many ailments. This plant has many ethnobotanical uses (Table 1), i.e. to treat headache and diabetes and as a diuretic and aphrodisiac. Its use as one of the main ingredients in a hallucinogenic drink has also been reported. ${ }^{14,15}$

Crassocephalum crepidioides ${ }^{7}$ is also called thickhead, fireweed, Okinawa spinach, and red flower ragleaf in English, Ebolo, or Ebire (Yoruba) in Nigeria. Its use is widespread in many tropical and subtropical regions, but is especially prominent in tropical Africa. It has also been widely cultivated in Asia due to its medicinal and nutritional properties. ${ }^{16,17}$ In southern Nigeria, $C$. crepidioides' leaves have been reported to be valuable in the management of indigestion, stomach ache, and fresh wounds (in Uganda) and its leaves' decoction is employed in Nigeria against headache (Table 1). In Tanzania, a mixture of the leaf sap of $C$. crepidioides and Cymbopogon giganteus is taken by mouth against epilepsy. Its dried leaves are used to stop nose bleeds and aid in sleeping. ${ }^{18}$
Launaea taraxacifolia (synonymous to Lactuca taraxacifolia) ${ }^{7}$ is a greenish leafy vegetable that is mainly eaten in the western part of Nigeria. This vegetable is eaten in most countries in Africa either cooked or as salad, i.e. Dahomey, Ghana, Senegal, and Sierra Leone. ${ }^{19}$ Most people in West Africa call L. taraxacifolia by the name African lettuce or wild lettuce. ${ }^{20}$ There are many ethno-medicinal applications of $L$. taraxacifolia. This leafy vegetable has been employed in managing many ailments for centuries, ailments such as diabetes, eye diseases (conjunctivitis), measles, skin diseases, and yaws (Table 1). Some cultures in Nigeria rubbed a concoction of its leaves on the limbs of toddlers to facilitate walking. ${ }^{21,22}$

Many studies have reported the green synthesis of leafy vegetable extracts employing various metals, i.e. the green synthesis of copper nanoparticles (NPs) using Ocimum sanctum $^{23}$ green synthesis of palladium NPs employing Origanum vulgare leaf extract ${ }^{24}$ lemon fruits and turmeric powder to steady the green synthesis employing manganese $\mathrm{NPs}^{25}$ and the synthesis of silver NPs (AgNPs) from Curcuma longa ${ }^{26}$ and Calotropis. Beside their nutritional benefits, leafy and non-cultivated vegetables (Figure 1) are known to possess therapeutic uses.13,27,28 However, many of these cheap but disease-preventing plant species are yet to be sufficiently studied and exploited. Hence, the aim of the present study was to investigate the phytochemical screening of these noncultivated vegetables' leaves extract and experimentally carry out characterization and application of these medicinal plants species' AgNPs as antiinflammatory and antioxidant agents and acetylcholinesterase inhibitors.

\section{MATERIALS AND METHODS}

Fresh green plants of Crassocephalum crepidioides (I.U. 0345), Ceratotheca sesamoides (I.U. 011), Ceiba pentandra (UILH/001/957), and Launaea taraxacifolia (UILH/002/1020) were obtained in December 2016 from "Oja-Oba" market in Ilorin, in Kwara State of Nigeria located in the rain forest zone at latitude $10^{\circ} 00^{\prime}$ North of the equator and longitude $8^{\circ} 00^{\prime}$ East of the Greenwich meridian. The plants were identified and authenticated at the Plant Biology Department, University of Ilorin, and voucher numbers collected. The authenticated plant materials were air-dried at ambient temperature for 2 weeks to completely remove the moisture content and to effectively prepare the plants for the next stage of preparation. After drying, the dried leaves were crushed into fine powder using a ceramic pestle and mortar and the samples were kept in an air-tight plastic container. 


\section{Equipment and reagents}

The equipment used comprised a pestle and mortal, extraction jar, rotary evaporator, centrifuging machine, ultravioletvisible (UV-Vis) spectrophotometer, and fourier transform infrared spectrophotometer (FTIR). The reagents included n-hexane, methanol, silver nitrate, ferric chloride, potassium ferricyanide, chloroform, sulfuric acid, lead acetate, acetic anhydride, potassium hydroxide, and Fehling solution. They were purchased from Labtrade and Sunaf Nig. Ltd. All solvents used were of analytical grade.

Preparation of extracts

Powdered C. sesamoides, C. pentandra, L. taraxacifolia, and C.

Table 1. Ethnomedicinal importance of the non-cultivated ${ }^{13-84}$

\begin{tabular}{|c|c|c|c|c|c|c|c|}
\hline $\mathrm{S} / \mathrm{N}$ & Plant name & Other names & Country found & Ethnomedicine & Biological activities & $\begin{array}{l}\text { Phytochemical } \\
\text { present }\end{array}$ & References \\
\hline 1 & $\begin{array}{l}\text { Crassocephalum } \\
\text { crepidioides }\end{array}$ & $\begin{array}{l}\text { Thickhead, } \\
\text { fireweed, red } \\
\text { flower ragleaf } \\
\text { (English); } \\
\text { Okinawa } \\
\text { spinach (Igbo); } \\
\text { Efo Ebolo or } \\
\text { Ebire (Yoruba), } \\
\text { Sekkoteka } \\
\text { Ekyakiragala } \\
\text { (Southern } \\
\text { Uganda) }\end{array}$ & $\begin{array}{l}\text { Uganda, } \\
\text { West African } \\
\text { countries, } \\
\text { Bangladesh, } \\
\text { India, and } \\
\text { Malaya }\end{array}$ & $\begin{array}{l}\text { Epilepsy, indigestion, } \\
\text { sickness, sleeping } \\
\text { disorder, stomach- } \\
\text { ache, swollen lips, } \\
\text { tumor, diabetes, } \\
\text { dizziness, fever, } \\
\text { headache, } \\
\text { hypertension, } \\
\text { leprosy, mental } \\
\text { diseases, peptic ulcer, } \\
\text { crop yield } \\
\text { improvement }\end{array}$ & $\begin{array}{l}\beta \text {-cell protection, } \\
\text { antidiabetic, } \\
\text { antioxidant, } \\
\text { anticholinesterases }\end{array}$ & $\begin{array}{l}\text { Polyphenolic, } \\
\text { pyrrolizidine alkaloid, } \\
\text { tannin, } \\
\text { dihydroisocoumarins, } \\
\text { monoterpenes }\end{array}$ & $52-58$ \\
\hline 2 & $\begin{array}{l}\text { Ceratotheca } \\
\text { sesamoides }\end{array}$ & $\begin{array}{l}\text { Eku (Yoruba- } \\
\text { Western } \\
\text { Nigeria); Bungu } \\
\text { (Nigeria); } \\
\text { Tchaba-laba } \\
\text { (Guinea Bissau); } \\
\text { Lalu-caminho } \\
\text { (Senegal) }\end{array}$ & $\begin{array}{l}\text { Senegal, Guinea } \\
\text { Bissau, Angola, } \\
\text { Namibia, } \\
\text { Tanzania, } \\
\text { Democratic } \\
\text { Republic of } \\
\text { Congo, Nigeria, } \\
\text { Botswana, } \\
\text { Mozambique, } \\
\text { Zimbabwe, and } \\
\text { Zambia }\end{array}$ & $\begin{array}{l}\text { Diarrhea, } \\
\text { conjunctivitis, } \\
\text { emollient and } \\
\text { lubricant, stomach } \\
\text { ache, leprosy, tumor, } \\
\text { relieve circumcision } \\
\text { pains, malaria, } \\
\text { aphrodisiac, jaundice, } \\
\text { snake bites and skin } \\
\text { ailments }\end{array}$ & $\begin{array}{l}\text { Antiviral, } \\
\text { antidiarrheal, } \\
\text { antiplasmodial, } \\
\text { antiplasmodial, } \\
\text { antioxidant, } \\
\text { hyaluronidase, } \\
\text { phospholipase A2, } \\
\text { proteolytic }\end{array}$ & $\begin{array}{l}\text { Flavonoids, } \\
\text { saponins, } \\
\text { alkaloids, } \\
\text { tannins, } \\
\text { phenols, } \\
\text { phenolics }\end{array}$ & $59-67$ \\
\hline
\end{tabular}

Yarin/Yamurin/

Odundun-

Odo (Yoruba);

Nononbarya, namijin dayii

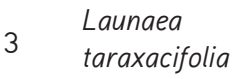

(Hausa); Ugu Nigeria, Benin, (Igbo); Yantotoé/ Togo, Ghana, yantoto (Fon); Cameroon Lantoto/ yantotoé (Mahi); Odôdô/

Odôdôlodôdô (Idaach)

Kapok, the Ceiba, Java cotton, Hara kapok, Silk cotton and Samauma is $4 \quad$ Ceiba pentandra also known as Rimi (Hausa), Bamtami (Fulani), Araba ogungun (Yoruba) and Akpi (lgbo)
Malaria, ulcer, against high blood pressure, diabetes mellitus, pain in fresh wounds, dysentery, eye diseases (conjunctivitis), measles, skin diseases, and yaws
Antioxidant, hypolipidemic/ antidiabetics, antibacterial, antimalarial, antiviral, anticancer
Flavonoids,phenols, $\quad 13,22,59,68-78$ chlorogenic acid
Antiviral, antidiarrheal,

. 


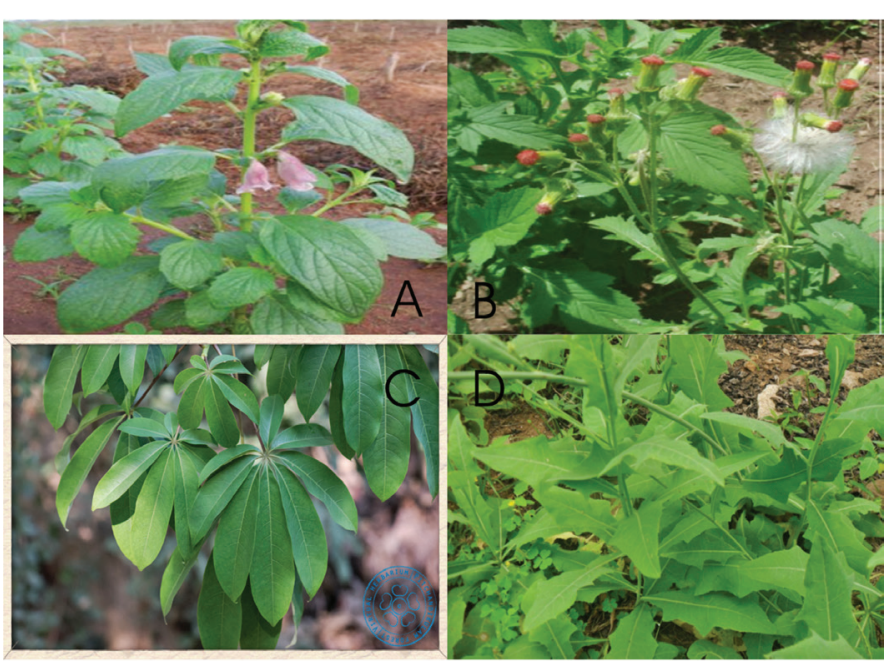

Figure 1. The leaves of A: Ceratotheca sesamoides, B: Ceiba pentandra, C: Crassocephalum crepidioides, D: Launaea taraxacifolia

crepidioides were macerated in $3 \mathrm{~L}$ of $\mathrm{n}$-hexane in an extraction jar such that the level of the solvent was above that of the plant materials. The macerated mixtures were then left for 72 $\mathrm{h}$ at ambient temperature. The extracts were filtered out from the macerated mixture using Whatman $185 \mu \mathrm{m}$ filter paper. The $n$-hexane extracts were concentrated in a vacuum rotary evaporator under reduced pressure and suitable temperature, transferred to appropriately labeled $250 \mathrm{~mL}$ beakers, and allowed to stand at ambient temperature to permit evaporation of residual solvents. The procedure was repeated using methanol after the residue of the $n$-hexane extract has been air-dried.

\section{Phytochemical screening}

Preparation for the test was done by pouring $3 \mathrm{~mL}$ of the leaf extracts into separate test tubes and diluting with $2-4 \mathrm{~mL}$ of deionized water. The various tests were carried out following the procedures described below. Standard techniques of screening and detecting secondary metabolites in plants were used. 29,30 The metabolites tested for were alkaloids, anthraquinones, cardiac glycosides, carbohydrates, flavonoids, saponins, steroids, phenolics, tannins, and triterpenes.

\section{Synthesis of silver nanoparticles}

The synthesis of AgNPs was carried out according to the method described in our previous study. ${ }^{31}$ Ten milliliters of the leaf extract was measured and poured into a clean $250 \mathrm{~mL}$ beaker and reacted with $100 \mathrm{~mL}$ of $0.01 \mathrm{M} \mathrm{AgNO}_{3}$ (prepared from stock $\mathrm{AgNO}_{3}-0.1 \mathrm{M}$ of $\mathrm{AgNO}_{3}$ ) from a burette (titration method) using $\mathrm{AgNO}_{3}$ as the titrant and the extracts as the titrant at ambient temperature. A color change to yellow was observed. The synthesized mixture was left for $24 \mathrm{~h}$ and then separated by centrifugation using a centrifuging machine. Clear liquid was decanted and the settled layer (NPs) was stored in a $5 \mathrm{~mL}$ plastic sample vial and labeled accordingly. The following nomenclature was given to the synthesized NPs: L. taraxacifolia (LT)-AgNPs, C. sesamoides (CS)-AgNPs, C. pentandra (CP)AgNPs, and C. crepidioides (CC)-AgNPs.

\section{Characterization of silver nanoparticles}

The characterization of LT-AgNPs, CS-AgNPs, CP-AgNPs, and CC-AgNPs was done using a combination of analytical and spectroscopic techniques, namely UV-Vis, FTIR, and scanning electron microscopy (SEM).

\section{Ultraviolet-visible spectroscopy}

The optical properties of the AgNPs of both plants were determined by UV-Vis spectroscopy on a Biochrom Libra PCB 1500 UV-VIS spectrophotometer. The wavelength with the highest absorbance was determined. The absorbance of AgNPs dispersed in a quartz cuvette with a $1 \mathrm{~cm}$ optical path was measured by withdrawing a small aliquot from the reaction mixture and a wavelength scan was taken every $60 \mathrm{~min}$, then $90 \mathrm{~min}$, and after $24 \mathrm{~h}$. The wavelength was varied from 320 $\mathrm{nm}$ to $620 \mathrm{~nm}$ for $L$. taraxacifolia, from $320 \mathrm{~nm}$ to $670 \mathrm{~nm}$ for $C$. crepidioides, from $320 \mathrm{~nm}$ to $620 \mathrm{~nm}$ for $C$. sesamoides, and from $320 \mathrm{~nm}$ to $620 \mathrm{~nm}$ for $C$. pentandra.

\section{Fourier transform infrared spectroscopy}

The functional groups present in the methanolic extract of $L$. taraxacifolia, C. crepidioides, C. sesamoides, and C. pentandra, which were responsible for capping and efficient stabilization of the synthesized AgNPs, were determined using a Shimadzu FTIR model IR8400s spectrophotometer. The solutions were dried at $75^{\circ} \mathrm{C}$ and the dried powders were characterized in the range $4000-400 \mathrm{~cm}^{-1}$ by $\mathrm{KBr}$ pellet method.

\section{Scanning electron microscopy}

NPs of these plants' extracts were viewed using an Ultra Plus FEGSEM (Carl Zeiss, Germany) and the size and shape of the NPs were determined using the Smart SEM Ver. 5 software (Carl Zeiss, Germany).

\section{Biological activities}

\section{Antiinflammatory activity}

\section{Cell stabilization membrane}

The antiinflammatory activity of these extracts was tested by in vitro human red blood cell (HRBC) membrane stabilization method. The reaction mixtures $(4.5 \mathrm{~mL})$ consisted of $2 \mathrm{~mL}$ hypotonic saline solution, phosphate buffer $(\mathrm{pH} 7.4)$, and $1 \mathrm{~mL}$ of test solution in normal saline; $0.5 \mathrm{~mL}$ of $10 \%$ rabbit RBC in normal saline was added. For control tests, $1 \mathrm{~mL}$ of isotonic solution was used. The mixtures were incubated at $560^{\circ} \mathrm{C}$ for $30 \mathrm{~min}$, cooled under running water, and centrifuged, while the absorbance of the supernatants was read at $560 \mathrm{~nm}$. Percentage membrane stabilizing activity was calculated as follows:

$\%$ stabilization=(100-O.D. of drug sample/O.D. of control) $\times 100$

The control represents $100 \%$ lysis. The result was compared with STD $(100 \mu \mathrm{g} / \mathrm{mL})$ treated samples. ${ }^{32,33}$

\section{Lipoxidase assay}

The inhibitory activity against lipoxygenases (LOXs) was studied using linoleic acid as substrate and lipoxidase as enzyme. Test samples were dissolved in $0.25 \mathrm{~mL}$ of $2 \mathrm{M}$ borate buffer $\mathrm{pH} 9.0$ and $0.25 \mathrm{~mL}$ of lipoxidase enzyme solution $(20,000 \mathrm{U} / \mathrm{mL})$ was 
added followed by incubation for $5 \mathrm{~min}$ at $250^{\circ} \mathrm{C}$. After that, $1.0 \mathrm{~mL}$ of lenoleic acid solution $(0.6 \mathrm{mM})$ was added followed by thorough mixing and absorbance was measured at $234 \mathrm{~nm}$. Indomethacin was used as reference standard. The percent inhibition was calculated from the following equation:

$\%$ inhibition=[(Abs control-Abs sample)/Abs control] $\times 100$

All tests and analyses were run in triplicate and averaged. ${ }^{34,35}$

\section{Antioxidant activity}

\section{2,2-Diphenyl-1-picrylhydrazyl (DPPH) activity}

The method employed was the one reported by Oguntoye et al. ${ }^{28}$ but with slight modifications. ${ }^{36}$ Mean \pm standard error of the mean of two independent experiments run in duplicate was used to present the results.

\section{2,2'-Azino-bis-(3-ethyl) benzothiazoline-6-sulfonic acid} (ABTS) radical cation scavenging (ABTS) activity

The ABTS radical cation decolorization assay based on the scavenging of ABTS + radicals by antioxidant components of the extracts was used. The assay follows the procedure of Oguntoye et al. ${ }^{28}$ with slight modifications. ${ }^{36}$ All analyses were performed in duplicate.

\section{Statistical analysis}

Mean \pm standard error of the mean of two independent experiments run in duplicate was used to present the results. The results are reported as mean \pm standard deviation.

\section{RESULTS AND DISCUSSION}

\section{Phytochemical screening}

The phytochemical constituents of the extracts of $C$. crepidioides, C. sesamoides, C. pentandra, and L. taraxacifolia are shown in Table 2. On the whole, polyphenol, flavonoids, triterpenes, and steroids were identified in all the plants' extracts. Alkaloids and saponins are absent in most of these plants except for methanol extract of $C$. crepidioides and hexane extract of $C$. pentandra. The hexane extracts of $C$. sesamoides gave poor results for most groups of secondary metabolites investigated as shown in Table 2. The phytochemical screening reveals that flavonoids are present in the various extracts.

\section{Characterization}

\section{UV-Vis spectroscopy study}

Visual inspection showed color changes. The color changes that were witnessed indicate the formation of $C$. crepidioides, $C$. sesamoides, C. pentandra, and L. taraxacifolia AgNPs as shown in Table 3. Many studies have shown that AgNPs displayed these color changes in aqueous solution due to the excitation of surface plasmon resonance (SPR) of AgNPs, and this was the first confirmation test to show that AgNPs were formed. ${ }^{37-41}$ The AgNPs formed were examined further by the use of UV-Vis spectroscopy, which is an important and popular tool used for characterization.

It was discovered that the aqueous extracts of $C$. sesamoides and $C$. pentandra were able to reduce silver nitrate to AgNPs at $450 \mathrm{~nm}$, being the surface plasmon absorbance peak among others. Figure 2 shows the curve in each spectrum of synthesized AgNPs absorbed in the wavelength range 380-440 $\mathrm{nm}$ of AgNPs of $C$. sesamoides and $C$. pentandra. The absorption spectra showed SPR and peaks at $380 \mathrm{~nm}$ in the case of $L$. taraxacifolia (Figure 2), whereas the bands for $C$. crepidioides were observed at $410 \mathrm{~nm}$ as shown in Figure 2. This peak falls within the range of specification for NPs reported by previous authors. ${ }^{42,43}$

\section{Fourier transform infrared spectroscopy study}

FTIR spectroscopy measurements were employed to recognize and identify the biological reducing functional group, which will give a hint about the likely group of organic compounds present in these wild and non-cultivated vegetables responsible for the reduction of the $\mathrm{Ag}^{+}$ions to elemental $\mathrm{Ag}^{0}$ and the ensuing capping resulting in efficient stabilization of the AgNPs formed. ${ }^{44}$ The FTIR spectra of the synthesized AgNPs of the

\section{Table 3. AgNPs' color changes observed}

\begin{tabular}{llll}
\hline & Plant name & Color change & \\
\hline & & Initial & Final \\
\hline 1 & Crassocephalum crepidioides & Black & Brown \\
\hline 2 & Ceratotheca sesamoides & Black greenish & Yellow \\
\hline 3 & Ceiba pentandra & Deep brown & Yellow \\
\hline 4 & Launaea taraxacifolia & Light yellow & Reddish brown \\
\hline
\end{tabular}

AgNPs: Silver nanoparticles Table 2. Phytochemical screening results

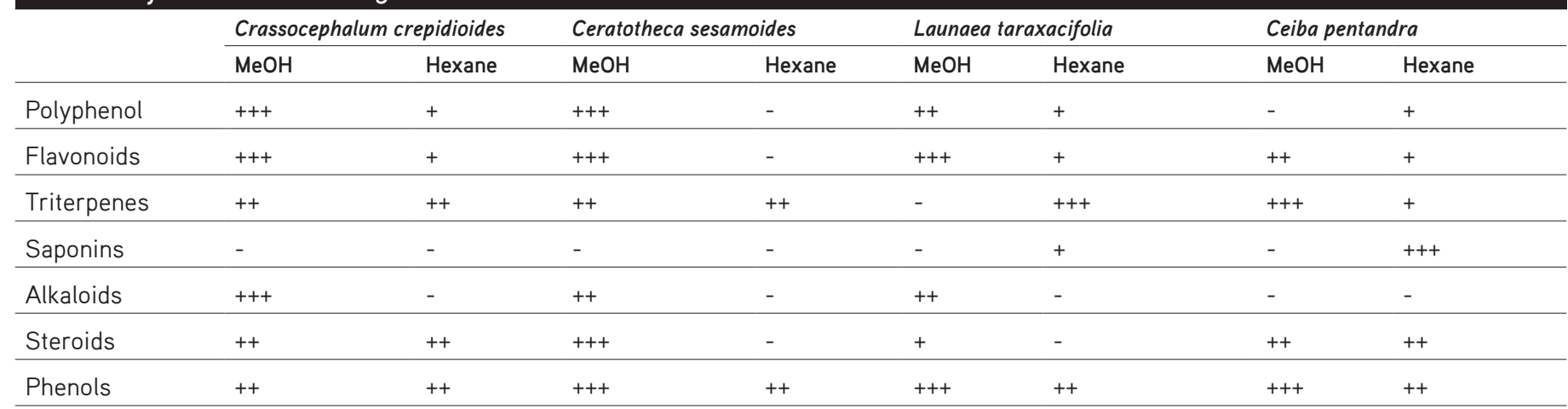

+++: Very good, ++=Good, +: Fair, -: Not present, MeOH: Methanol 


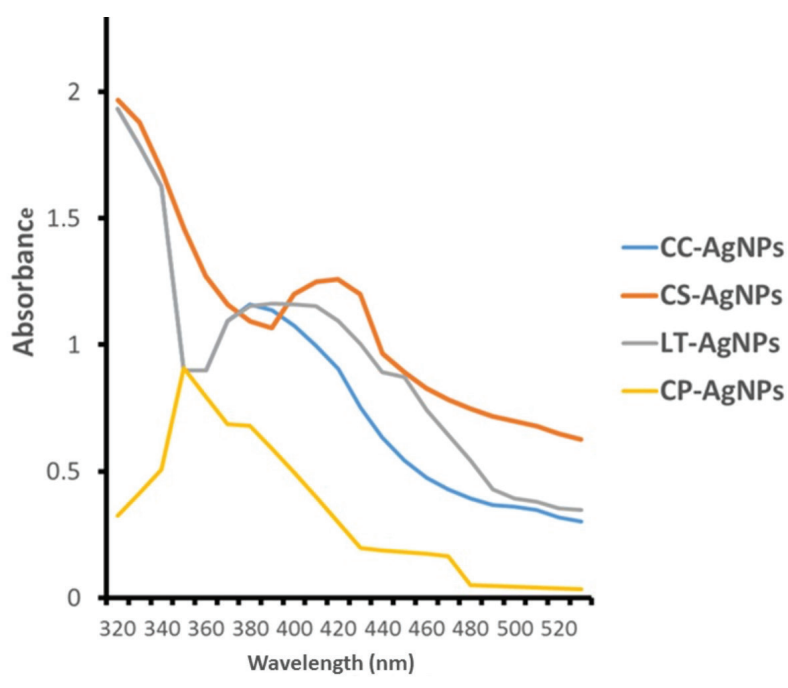

Figure 2. UV-visible spectra of the synthesized AgNPs

UV: Ultraviolet, AgNPs: Silver nanoparticles, CC: Crassocephalum crepidioides, CS: Ceratotheca sesamoides, LT: Launaea taraxacifolia, CP: Ceiba pentandra

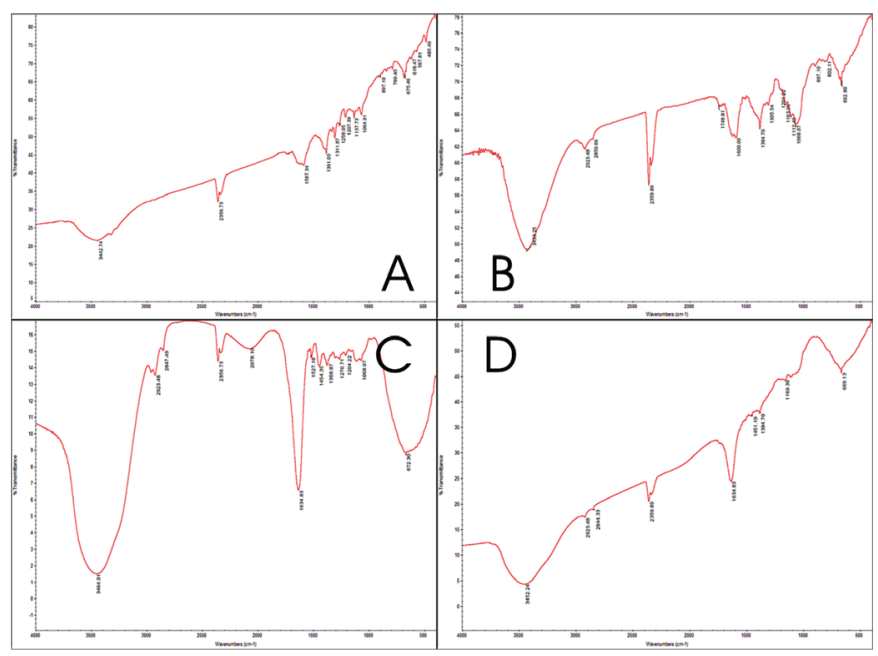

Figure 3. FTIR spectra of $A=C C-A g N P s ; B=C S-A g N P s ; C=C P-A g N P s ; D=L T-$ AgNPs

FTIR: Fourier transform infrared, CC: Crassocephalum crepidioides, CS: Ceratotheca sesamoides, LT: Launaea taraxacifolia, CP: Ceiba pentandra, AgNPs: Silver nanoparticles

four vegetables, i.e. $A=C C-A g N P s, B=C S-A g N P s, C=C P-A g N P s$, and $D=L T-A g N P s$, are shown in Figure 3. The infrared spectrum of CP-AgNPs showed the presence of an $\mathrm{O}-\mathrm{H}$ functional group with a broad band at $3464.94 \mathrm{~cm}^{-1}$, while the IR spectrum of CPAgNPs further revealed a $\mathrm{C}=\mathrm{C}$ structure with medium intensity at a wave number of $1634.33 \mathrm{~cm}^{-1}$, which is $\mathrm{sp}^{2}$ carbon. The IR spectrum of CS-AgNPs showed a very broad band at 3433.48 $\mathrm{cm}^{-1}$, which was assigned to a $-\mathrm{OH}$ stretch. It showed a very sharp absorption band at $1748.81 \mathrm{~cm}^{-1}$, which was assigned to a $\mathrm{C}=\mathrm{O}$ stretch, while there was a $\mathrm{C}=\mathrm{C}$ functional group at a wave number of $1600 \mathrm{~cm}^{-1}$. Clear and broad absorbance bands were observed at $3452.24(-\mathrm{OH}), 2923.48-2844.33(\mathrm{C}-\mathrm{H}$, stretching), 1634.83 ( $\mathrm{C}=\mathrm{C}$, stretching), 1451.19-1384.70 ( $\mathrm{C}-\mathrm{H}$, bending), and 1169.39 (C-O) for the LT-AgNPs synthesized (Figure 3). The intense and broad bands observed at around $3452 \mathrm{~cm}^{-1}$ for all the
AgNPs was due to the $\mathrm{O}-\mathrm{H}$ stretching, which gives an indication for the presence of polyphenols. A medium band observed at around $1634 \mathrm{~cm}^{-1}$ in both the synthesized NPs was attributed to $-\mathrm{C}=\mathrm{C}$ - stretching. The peaks at $1451 \mathrm{~cm}^{-1}$ correspond to $\mathrm{C}-\mathrm{H}$ stretching of the aromatic compounds (Figure 3 ). The IR spectrum of CC-AgNPs showed an intense and broad band at 3442.74 (-OH, stretching), 1587.34 ( $\mathrm{C}=\mathrm{C}$, stretching), 1391.031311.87 ( $\mathrm{N}=\mathrm{O}$, stretching), and 1258.05-1064.91 (C-O, stretching). This indicated the presence of alkaloids, flavonoids, and others in this plant extract. The peaks at $1587 \mathrm{~cm}^{-1}$ correspond to $\mathrm{C}-\mathrm{H}$ stretching of the aromatic compounds. As shown in Figure 3, most of these spectra proved distinctive functional groups of compounds, i.e. alkaloids, coumarins, flavonoids, and phenolic acids, which may all have had an active role in the reduction and capping of the synthesized AgNPs.

\section{Scanning electron microscope}

The scanning electron microscope identifies the surface characteristics, morphology, and the distribution of the CCAgNPs, CS-AgNPs, CP-AgNPs, and LT-AgNPs depicted in the SEM micrograph (Figure 4), to determine the silver concentration of the NPs. AgNPs generally show a typical absorption characteristic peak at approximately $3 \mathrm{keV}$ due to the surface plasma resonance phenomenon..$^{45}$ The cracked lines in the SEM micrographs (Figure 1A-1D) would enhance laminar flow, indicating the potential of the AgNPs for toxicant removal. ${ }^{46,47}$ The NPs synthesized by these non-cultivated vegetables were

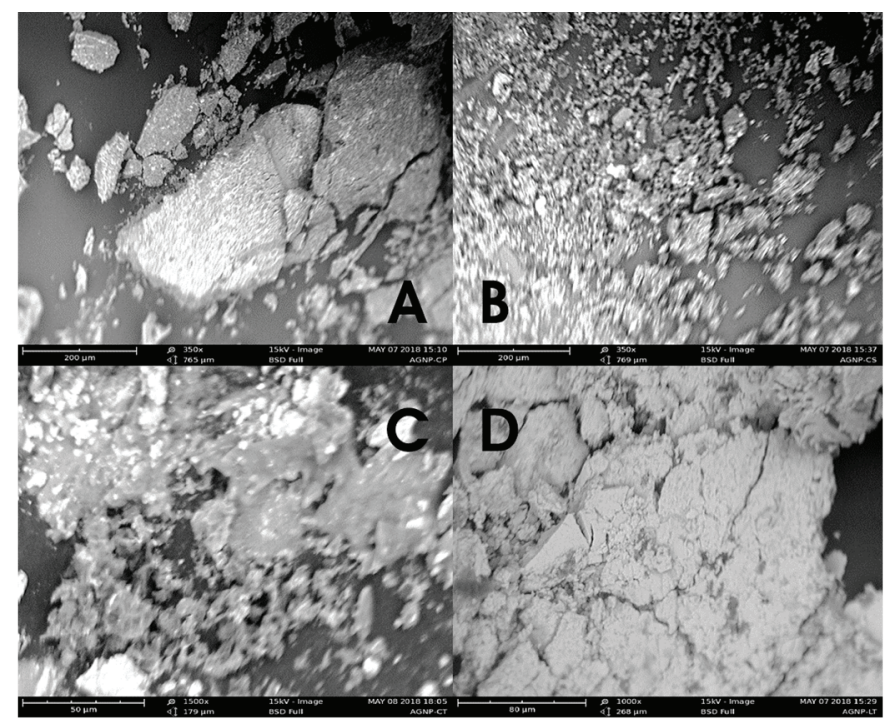

Figure 4. Scanning electron microscope picture: $A=C C-A g N P s ; B=C S-$ AgNPs; C=CP-AgNPs; D=LT-AgNPs

CC: Crassocephalum crepidioides, CS: Ceratotheca sesamoides, LT: Launaea taraxacifolia, CP: Ceiba pentandra, AgNPs: Silver nanoparticles

highly agglomerated except for CC-AgNPs, which displayed a scattered morphology (Figure 1). MubarakAli et al..$^{48}$ ascribes this cluster to a dehydration-induced combination of Ag NPs. However, CS-AgNPs, CP-AgNPs, and LT-AgNPs showed a trend in terms of differences in the dimensions and magnitude of the synthesized NPs. This can be accredited to the fact that the bigger and bulkier NPs can hold more Ag. 


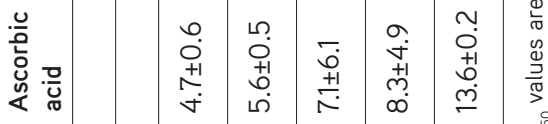

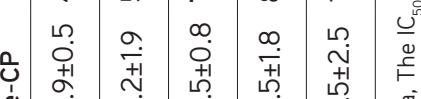

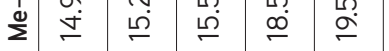

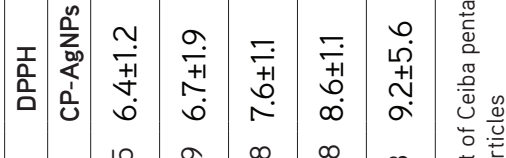

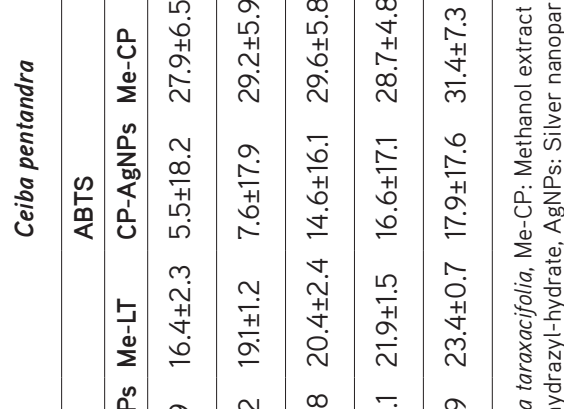

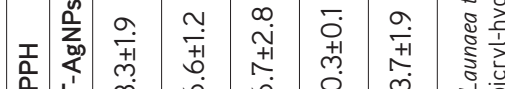

高

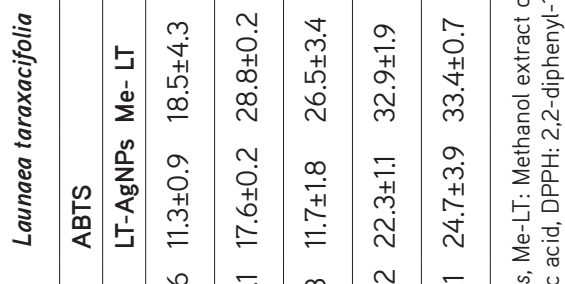

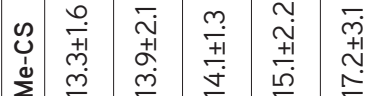

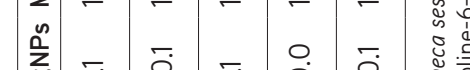

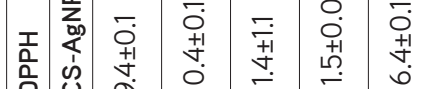

(3)

$-F=\leftarrow$ ธิँ

乌

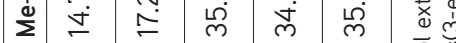

急

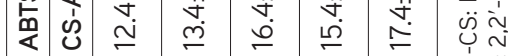

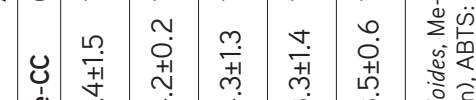

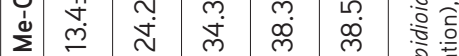

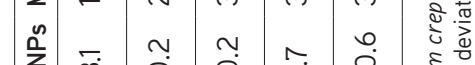

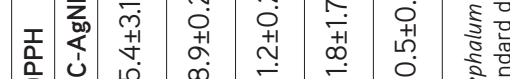

范

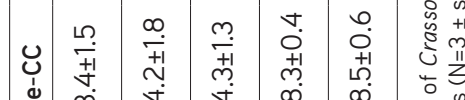

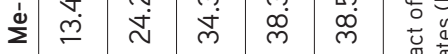

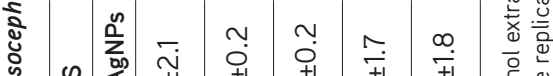

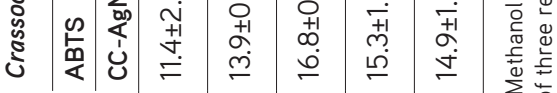

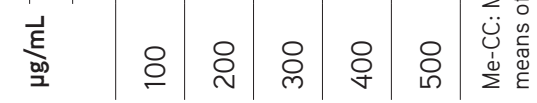

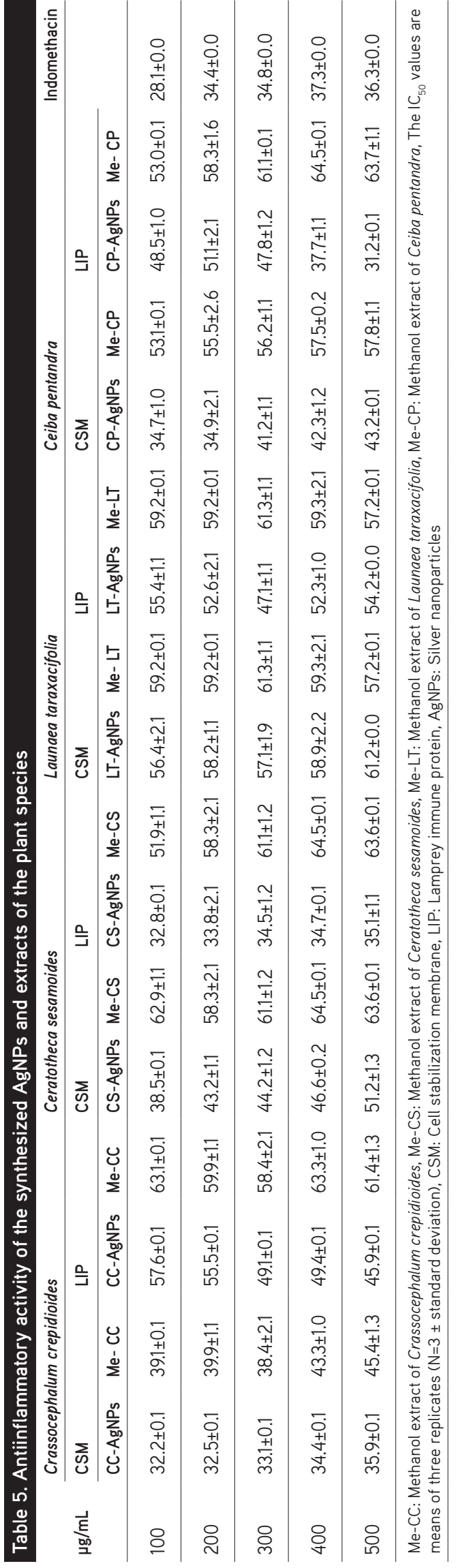




\section{Biological activities}

\section{Antioxidant activity}

The methanolic extracts of the four non-cultivated vegetables with their corresponding synthesized NPs were evaluated and compared employing two different assays for their antioxidant activity as shown in Table 4. The AgNPs and the methanol extract for each of these plants were evaluated for in vitro activity employing DPPH and ABTS assays. The results are expressed in terms of $\mathrm{IC}_{50}$ (the concentration that caused $50 \%$ inhibition) and are presented in Table 4. These were obtained by in vitro method at various concentrations $(100,200,300 . .500$ $\mu \mathrm{g} / \mathrm{mL}$ ) of the extracts and AgNPs formed. The synthesized AgNPs of the non-cultivated vegetables and the extracts tend to display significant antioxidant activity at the dose $100 \mu \mathrm{g} / \mathrm{mL}$ concentration; this was noted with the positive control as well. The higher the concentration the lower the antioxidant effect that was observed, although there was a climax at $400 \mu \mathrm{g} / \mathrm{mL}$ as shown in Table 4. Table 4 shows that there is an obvious trend: the synthesized AgNPs displayed better activity when compared to the extracts of these plants, i.e. AgNPs from $C$. crepidioides, C. sesamoides, L. taraxacifolia, and C. pentandra displayed better in vitro antioxidant activity $\left(\mathrm{IC}_{50}\right.$ : 11.4, 12.4, 11.3 , and $5.5 \mu \mathrm{g} / \mathrm{mL}$ ) with the ABTS assay and $\left(\mathrm{IC}_{50}: 15.4,9.4\right.$, 13.3 , and $6.4 \mu \mathrm{g} / \mathrm{mL}$ ) using the DPPH assay but the methanol extracts of these plants displayed values lower than those of the former. CP-AgNPs, CC-AgNPs, and LT-AgNPs exhibited the most significant antioxidant effect against $\mathrm{ABTS}\left(\mathrm{IC}_{50}: 5.5,11.3\right.$, and $11.4 \mu \mathrm{g} / \mathrm{mL}$ ), while CP-AgNPs and CS-AgNPs displayed the most significant antioxidant activity against $\mathrm{DPPH}\left(\mathrm{IC}_{50}: 6.4\right.$ and $9.4 \mu \mathrm{g} / \mathrm{mL}$ ) when compared to the positive control used, ascorbic acid $\left(\mathrm{IC}_{50}: 4.7 \mu \mathrm{g} / \mathrm{mL}\right)$. Most of the AgNPs formed showed the most significant result at $100 \mu \mathrm{g} / \mathrm{mL}$, although the positive control gave the best result at this dose as well (Table 4). Higher plants always contain constituents and substances with antioxidant effects. Flavonoids are among these naturally occurring substances that are widely renowned to exert scavenging ability against superoxide, free, and hydroxyl radicals. ${ }^{49}$ In the present study, we assessed the antioxidant effects of the AgNPs of the non-cultivated vegetables and their methanolic extracts because of the multifaceted and complex nature of compounds in plants; the antioxidant nature of these AgNPs and their extracts cannot be studied by only a single method. As a result of this, the generally accepted assays, i.e. DPPH and ABTS methods, were used in the present study. CPAgNPs displayed significant antioxidant activity in both assays employed, but CS-AgNPs only showed good antioxidant activity in the DPPH assay only. The DPPH and ABTS antioxidant assays proved that these neglected vegetables with their synthesized AgNPs show antioxidant activity. Bello et al. ${ }^{15}$ examined the antioxidant effects of the leaves of $L$. taraxacifolia and $C$. pentandra (methanol extracts). These plant species displayed significant antioxidant activity when the ABTS assay was employed as compared with ascorbic acid.

\section{Antiinflammatory activity}

The methanolic extracts of the four non-cultivated vegetables with their corresponding synthesized NPs were evaluated and compared using cell-based assays for their antiinflammatory activity as shown in Table 5. The AgNPs and the methanol extract for each of these plants were evaluated for in vitro activity employing the HRBC membrane stabilization method and lipoxidase assay. The results are expressed in terms of $\mathrm{IC}_{50}$ (the concentration that caused $50 \%$ inhibition) and are presented in Table 5. These were carried out with an in vitro method at various concentrations $(100,200,300 \ldots .500 \mu \mathrm{g} /$ $\mathrm{mL}$ ) of the extract. The extract tends to display a significant antiinflammatory activity at $100 \mu \mathrm{g} / \mathrm{mL}$ concentration; this was noted with the positive control as well. The higher the concentration the lower the antiinflammatory effect that was seen, although there was a climax at $400 \mu \mathrm{g} / \mathrm{mL}$ as shown in Table 5. Table 5 shows that there is an obvious trend: the synthesized AgNPs displayed better activity when compared to the extracts of these plants, i.e. AgNPs from $C$. crepidioides, $C$. sesamoides, C. pentandra, and L. taraxacifolia displayed better in vitro antiinflammatory activity $\left(\mathrm{IC}_{50}: 32.2,38.5,56.4\right.$, and $34.7 \mu \mathrm{g} / \mathrm{mL})$ against $\mathrm{HRBC}$ membrane and $\left(\mathrm{IC}_{50}: 57.6,32.8\right.$, $55.4,48.5 \mu \mathrm{g} / \mathrm{mL}$ ) against LOXs but the methanol extracts of these plants displayed values lower than those of the former. AgNPs from C. crepidioides, C. sesamoides, L. taraxacifolia, and C. pentandra exhibited $\mathrm{IC}_{50}$ of $32.2,38.5,56.4$, and $34.7 \mu \mathrm{g} / \mathrm{mL}$ against $\mathrm{HRBC}$ membrane and showed inhibitory activity $\left(\mathrm{IC}_{50}\right.$ : $57.6,32.8,55.4$, and $48.5 \mu \mathrm{g} / \mathrm{mL}$ ) against LOXs. CC-AgNPs and CP-AgNPs exhibited the most significant inhibitory activity against HRBC $\left(\mathrm{IC}_{50}\right.$ : 32.2 and $\left.34.7 \mu \mathrm{g} / \mathrm{mL}\right)$, while CS-AgNPs and LT-AgNPs displayed the most significant inhibitory activity against LOXs ( $\left(\mathrm{C}_{50}: 32.8\right.$ and $\left.48.5 \mu \mathrm{g} / \mathrm{mL}\right)$ when compared to the positive control using indomethacin $\left(\mathrm{IC}_{50}: 28.1 \mu \mathrm{g} / \mathrm{mL}\right)$. Most of the AgNPs formed showed the most significant result at $100 \mu \mathrm{g} / \mathrm{mL}$, although the positive control gave the best result at this dose as well. CS-AgNPs and LT-AgNPs displayed good activity against the LOX assay employed; they could serve as good LOX inhibitors. It was very surprising that they displayed moderate activity in the other assay used. Some authors have reported the antiinflammatory activity of $C$. pentandra through the LOX assay. It was reported that the methanol extract of its leaves displayed inhibitory activity against LOX with an $\mathrm{IC}_{50}$ of $102.4 \mu \mathrm{g} / \mathrm{mL}$ when compared with that of the positive control, $90.4 \mu \mathrm{g} / \mathrm{mL}$ (indomethacin). ${ }^{22}$ This neglected vegetable's ( $C$. pentandra) extracts exhibited inhibitory activity against LOX with an $\mathrm{IC}_{50}$ of $53.6 \mu \mathrm{g} / \mathrm{mL}$. LOXs are present in the airway and stomach epithelium, leukocytes, and gut cells, and they aid in the introduction of an oxygen molecule to the 5 -position of arachidonic acid to give the intermediate (5S)hydroxy-(6E,8Z,11Z,14Z)-eicosatetraenoic acid or 5-HETE. This is an important aspect of antiinflammatory activity in the LOX assay, hence inhibiting the biological genesis of leukotriene and 5-HETE. Hence, the search for specific inhibitors of LOX activity from medicinal plants is ongoing and imperative. LOX inhibitors, i.e. CS-AgNPs and LT-AgNPs, could possess some great advantages for the treatment of allergic rhinitis, arthritis, asthma, atherosclerosis, cancer, osteoporosis, and psoriasis. ${ }^{50,51}$ 


\section{CONCLUSION}

Future studies will be carried out using various chromatographic techniques, spectroscopic techniques, and mass spectrometry to isolate and elucidate the bioactive compounds in the active fractions of wild and non-cultivated vegetables. The specific receptors these active plants' extracts and their corresponding synthesized AgNPs might be acting on to elicit antiinflammatory effects will be determined. There should be in vivo testing on small mammals to verify the antiinflammatory effects of these compounds in living organisms. Because AgNPs of both $C$. crepidioides and $C$. sesamoides significantly inhibited inflammatory response, it would be interesting to assay other plants from these families for antiinflammatory activity. The phytobiological facilitated production of AgNPs from selected non-cultivated vegetables proves to be ecofriendly and successful. In the current research, it has been shown that the synthesis of AgNPs by a simple, costeffective, nontoxic, and reproducible green chemistry method allows for better antioxidant and antiinflammation worth. This study reports for the first time the synthesis, characterization, and antiinflammatory and antioxidant activities of CS-AgNPs, CP-AgNPs, and LT-AgNPs. The synthesized AgNPs were found to be stable and the FTIR evidence suggested that the phytochemicals might have played an important role in the reduction and stabilization of AgNPs. This work showed that the synthesized AgNPs from non-cultivated vegetables can find relevance and application in health, drugs, food, and environmental science. The evidence herein further confirmed their ethnopharmacological applications.

Conflicts of interest: No conflict of interest was declared by the authors. The authors alone are responsible for the content and writing of the paper.

\section{REFERENCES}

1. Antia BS, Akpan EJ, Okon PA ,Umoren IU. Nutritive and Anti. Nutritive Evaluation of sweet potatoes (Ipomoea batatas) Leaves. Pak J Nutr. 2006;5:166-168

2. Dhellot JR, Matouba E, Maloumbi MG, Nzikou JM, Safoungoma DG, Linder M, Desobry S, Parmentier M. Extraction, chemical composition and nutritional characterization of vegetable oils: case of Amaranthus hybridus (var 1 and 2) Longo Brazzaville. Afr J Biotech. 2006;5:10951101.

3. Omoti O, Okyi PA. Characterization and composition of the pulp oil and cake of the African Dacryodes edulis. J Sci Food Agric. 1987;38:67-70.

4. Edmonds JM, Chweya JA. Promoting the conservation and use of under-utilized and neglected crops: Black nightshades (Solanum nigrum L.) and related species. International Plant Genetic Resources Institute;Rome, Italy;1997:1-90.

5. Fleuret $A$. The role of wild foidage plants in the Characterization and diet. A case study from Lushuto, Tanzania. Ecol Food Nutr. 1979;8:8793.

6. Onyenuga VA, Fetuga BL. First National seminar on fruits and vegetables. In: proc and Recom. Nithort; Ibadan, Nigeria;1995.

7. Burkill HM. In: The useful plants of West tropical Africa, Vol 3, Royal Botanic Gardens; Kew, UK;1985:133-136.
8. Van Wyk BE, Gericke N. People's Plants: A Guide to Useful Plants of Southern Africa. Briza Publications; Pretoria, South Africa;2000:102.

9. Vanderjagt DJ, Freiberger C, Vu HTN, Mounkaila G, Glew RS, Glew RH. The trypsin inhibitor content of 61 wild edible plant foods of Niger. Plant Foods Hum Nutr. 2000;55:335-346.

10. Grubben GJH, Denton OA. Ceratotheca sesamoides Endl. In: Bedigian D, Adetula OA, eds. Plant Resources of Tropical Africa, vol. 2. Vegetables PROTA Foundation. Backhuys Publishers; Wageningen, Netherlands; 2004:56.

11. Bedigian D. Evolution of sesame revisited: domestication, diversity and prospects. Genet Resour Crop Evol. 2003;50:779-787.

12. Bedigian D, Adetula AO. Ceratotheca sesamoides Endl. Prota 2: Vegetables/Legumes. PROTA, Wageningen; The Netherlands; 2004;3436.

13. Bello OM, Zaki AA, Khan IS, Fasinu PS, Ali Z, Khan IA, Usman LA, Oguntoye OS. Assessment of selected medicinal plants indigenous to West Africa for antiprotozoal activity. S Afr J Bot. 2017;113:200-211.

14. Adebisi AA. Population of Neglected Indigenous Leafy Vegetables among the Yoruba tribe of South West Nigeria. CERNARD Development Series 06 CERNARD; Ibadan, Nigeria; 2000:86.

15. Bello OM, Ogbesejana AB, Tijjani A. Lipoxygenase (Lox) Inhibitory Activity of Leaves of Ceiba Pentandra (L.) Gaertn: A Neglected Vegetable from Nigeria. FUDMA Journal of Sciences. 2018;2:79-82.

16. Burkill HM. The useful plants of west tropical Africa 2ed. Royal Botanical Garden; Kew, London; 1995:160-164.

17. Robert OB. The Typification of Crassocephalum moench and Gynura cass. Kew Bulletin;London: 1955;10:455-465.

18. Arawande JO, Komolafe EA, Imokhuede B. Nutritional and phytochemical compositions of fireweed (Crassocephalum crepidioides). J Agr Tech. 2013;9:439-449.

19. Arawande JO, Amoo IA, Lajide L. Chemical and phytochemical composition of wild lettuce launaea taraxacifolia. JAPES. 2013;2:25-30.

20. Lydia EK. Safety Assessment of the Ethanolic Leaf Extract of Launaea Taraxacifolia (Willd) of the Family Asteraceae in Rodents. Master Thesis, Kwame Nkrumah University of Science and Technology, Kumasi, Ghana. 2012:110.

21. Adebisi AA. Launaea taraxacifolia (Willd.) Amin ex C. Jeffrey. In: PROTA 2: Vegetables/Legumes. Kew Bull. London. 1966;18:474.

22. Oluwasesan MB, Ogbesejana AB, Uduma A. Launaea taraxacifolia; a Neglected Vegetable from Nigeria, its Anti-inflammatory and Antioxidant Activities. Chem Search J. 2018;9:9-12.

23. Sathiraju A, Yathapu S, Bojja S, Ganghishetti B, Singh AK. Characterization of Green Synthesized Copper Nanoparticles Stabilized by Ocimum Leaf Extract. Mater Res Soc Symp Proc (India). 1704:6.

24. Mohammed RS, Zuhur J, Qandeel A, Mujeeb K, Mufsir K, Mohamed EA, Hamad ZA Abdulrahman, A-W, Rafiq HS, Merajuddin K, Syed FA. Green synthesis and characterization of palladium nanoparticles using origanum vulgare I. Extract and their catalytic activity. Molecules. 2017;22:165.

25. Jayandran M, Muhamed HM, Balasubramanian V. Green synthesis and characterization of Manganese nanoparticles using natural plant extracts and its evaluation of antimicrobial activity. J Appl Pharm Sci. 2015;5:105-110. 
26. Ramar M. Synthesis of Silver Nanoparticles using Natural products from Acalypha indica and Curcuma longa. Int J Pharm Res Bio-Sci. 2015;4:151-164.

27. Bello OM, Ibitoye T, Adetunji C. Assessing antimicrobial agents of Nigeria flora Journal of King Saud University - Science; 2018.

28. Oguntoye S, Oluwasesan BM, Idowu OE, Dada AO, Hamid AA. Acetylcholinesterase inhibition and antioxidant evaluation of polyphenolic fractions and oil from four melon seeds used as condiments in Nigeria. Carpathian J Food Sci Technol. 2018;10:82-94.

29. Sofowora EA. Medicinal plants and traditional medicine in Africa. $2^{\text {nd }}$ ed. Spectrum Books limited Ibadan; Nigeria;1993:289.

30. Trease GE, Evans WC. A Textbook of Pharmacognosy, $13^{\text {th }}$ ed. Bailliere Tindall Ltd; London; 1989:134.

31. Dada AO, Inyinbor AA, Idu IE, Bello OM, Oluyori AP, Adelani-Akande TA, Okunola AA, Dada O. Effect of operational parameters, characterization and antibacterial studies of green synthesis of Silver Nanoparticles, using Tithonia diversifolia. Peer J. 2018;6:e5865.

32. Oyedapo OO, Akindele VR, Okunfolami KO. Effects of the extracts of Olax subcorpiodes and Aspilia Africana on bovine red blood cells. Phytotherapy Res. 1997;11:305-306.

33. Oyedapo OO, Akinpelu BA, Orefuwa SO. Anti-inflammatory effects of Theobroma cacao, L. root extract. J Tropical Med Plants (Malaysia). 2004;5:161-166.

34. Shinde UA, Kulkarni KR, Phadke AS, Nair AM, Dikshit VJ, Saraf MN. Mastcell stabilizing and lipoxygenase inhibitory activity of Cedrus deodara (Roxb.) Loud wood Oil. Indian J Exp Biol. 1999;37:258-261.

35. Steinhilber D. 5-Lipoxygenase: a target for anti-inflammatory drugs revisited. Curr Med Chem. 1999;6:69-83.

36. Atolani O, Omere J, Otuechere CA, Adewuyi A. Antioxidant and cytotoxicity effects of seed oils from edible fruits. J Acute Dis. 2012;1:130-134.

37. Kotakadi VS, Gaddam SA, Rao YS, Prasad TNV, Reddy VA, Gopal SDVR. Biofabrication of silver nanoparticles using Andrographis paniculata. Eur J Med Chem. 2014;73:135-140.

38. Kuppusamy P, Yusoff MM, Maniam GP, Govindan N. Biosynthesis of metallic nanoparticles using plant derivatives and their new avenues in pharmacological applications - an updated report. Saudi Pharmaceutical Journal; 2014.

39. Sharma S, Kumar S, Bulchandani BD, Taneja S, Banyal S. Green synthesis of silver nanoparticles and their antimicrobial activity against Gram-positive and Gram-negative bacteria. IJBB. 2013;4:711-714.

40. Stephen A, Seethalakshmi S. Phytochemical synthesis and preliminary characterization of silver nanoparticles using Hesperidin. Int J Nanosci. 2013;3-7.

41. Zhang, XF, Liu ZG, Shen W, Gurunathan S. Silver nanoparticles: Synthesis, characterization, properties, applications, and therapeutic approaches. Int J Mol Sci. 2016;17:1534.

42. Sigamoney M, Shaik S, Govender P, Krishna SBN, Sershen N. African leafy vegetables as bio-factories for silver nanoparticles: a case study on Amaranthus dubius C Mart. Ex Thell. S Afr J Bot. 2016;103:230-240.

43. Fafal T, Taştan P, Tüzüna BS, Ozyazici M, Kivcak B. Synthesis, characterization and studies on antioxidant activity of silver nanoparticles using Asphodelus aestivus Brot. aerial part extract. S Afr J Bot. 2017;112:346-353.
44. Kumar DA, Palanichamy V, Roopan SM. Green synthesis of silver nanoparticles using Alternanthera dentata leaf extract at room temperature and their antimicrobial activity. Spectrochim Acta A Mol Biomol Spectrosc. 2014;127:168-171.

45. Prasad TN, Kambala VSR, Naidu R. Phyconanotechnology: synthesis of silver nanoparticles using brown marine algae Cystophora moniliformis and their characterization. J Appl Phycol. 2012;25:177-182.

46. Dada AO, Adekola FA, Odebunmi EO. Kinetics and equilibrium models for sorption of $\mathrm{Cu}(\mathrm{II})$ onto a novel manganese nano-adsorbent. J Dispersion Sci Technol. 2016;37:119-133.

47. Dada AO, Adekola FA, Odebunmi EO. Liquid phase scavenging of $\mathrm{Cd}(\mathrm{II})$ and $\mathrm{Cu}(\mathrm{II})$ ions onto novel nanoscale zerovalent manganese (nZVMn): equilibrium, kinetic and thermodynamic studies. Environmental Nanotechnology, Monitoring Management. 2017;8:63-72.

48. MubarakAli D, Thajuddin N, Jeganathan K, Gunasekaran, M. Plant extract mediated synthesis of silver and gold nanoparticles and its antibacterial activity against clinically isolated pathogens. Colloids Surf B Biointerfaces. 2011;85:360-365.

49. Choi CW, Kim SC, Hwang SS, Choi BK, Ahn HJ, Lee MY, Park SH, Kim SK. Antioxidant activity and free radical scavenging capacity between Korean medicinal plants and flavonoids by assay-guided comparison. Plant Sci. 2002;163:1161-1168.

50. Fukuishi N, Takada T, Fukuyama Y, Akagi M. Antiallergic effect of ardisiaquinone $A$, a potent 5-lipoxygenase inhibitor. Phytomedicine. 2001;8:460-464.

51. Dana A, Ilse Z, Dingermann T, Müller WE, Steinhilber D, Werz O. Hyperforin is a dual inhibitor of cyclooxygenase-1 and 5-lipoxygenase. Biochem Pharmacol. 2002;64:1767-1775.

52. Asada Y, Shiraishi M, Takeuchi T, Osawa Y, Furuya T. Pyrrolizidine alkaloids from Crassocephalum crepidioides. Planta Medica. 1985;51:539-540.

53. Wilfried R, Kammermeier L, Schramm S, Towfique N, Adedeji NA, Ajayi SA, Poppenberger B. Quantification of the pyrrolizidine alkaloid jacobine in crassocephalum crepidioides by cation exchange highperformance liquid chromatography. Phytochem Anal. 2018;29:48-58.

54. Aniya Y, Koyama T, Miyagi C, Miyahira M, Inomata C, Kinoshita S, Ichiba $T$. Free radical scavenging and hepatoprotective actions of the medicinal herb, Crassocephalum crepidioides from the Okinawa Islands. Biol Pharm Bull. 2005;28:19-23.

55. Musa AA, Adekomi DA, Tijani AA, Muhammed OA. Some of the effect of Crassocephalum crepidioides on the frontal cortex, kidney, liver and testis of adult male Sprague Dawley rats: microanatomical study. Eur J Exp Biol. 2011;1:228-235.

56. Tomimori K, Nakama S, Kimura R, Tamaki K, Ishikawa C, Mori N. Antitumor activity and macrophage nitric oxide producing action of medicinal herb, Crassocephalum crepidioides. BMC Complement Altern Med. 2012;12:78.

57. Bukola AC, Oboh G, Oyeleye SI, Ejakpovi II, Boligon AA, Athayde ML. Blanching alters the phenolic constituents and in vitro antioxidant and anticholinesterases properties of fireweed (Crassocephalum crepidioides). J Taibah Univers Med Sci. 2015;10:419-426.

58. Ssegawa P, Kasenene JM. Medicinal plant diversity and uses in the Sango bay area, Southern Uganda. J Ethnopharmacol. 2007;113:521540.

59. Obi RK, Iroagba II, Ojiako OA. Virucidal potential of some edible Nigerian vegetables. Afr J Biotechnol. 2006;5:1785-1788. 
60. Toyin MY, Khadijat OF, Saoban SS, Olakunle AT, Abraham BF, Luqman QA. Antidiarrhoeal activity of aqueous leaf extract of Ceratotheca sesamoides in rats. Bangl J Pharmacol. 2012;7:14-20.

61. Benoit-Vical F, Soh PN, Saléry M, Harguem L, Poupat C, Nongonierma R. Evaluation of Senegalese plants used in malaria treatment: focus on Chrozophora senegalensis. J Ethnopharmacol. 2008;116:43-48.

62. Konan Y, Witabouna KM, Bassirou B, Kagoyire K. Antioxidant activity and total phenolic content of nine plants from Côte d'Ivoire (West Africa). J Appl Pharm Sci 2014;4:036-041.

63. Molander M, Nielsen L, Søgaard S, Staerk D, Rønsted N, Diallo D, Chifundera KZ, Van Staden J, Jäger AK. Hyaluronidase, phospholipase A2 and protease inhibitory activity of plants used in traditional treatment of snakebite induced tissue necrosis in Mali, DR Congo and South Africa J Ethnopharmacol. 2014;157:171-180.

64. Nadembega P, Boussim JI, Nikiema JB, Poli F, Antognoni F. Medicinal plants in Baskoure, Kourittenga Province, Burkina Faso: an ethnobotanical study. J Ethnopharmacol. 2011;133:378-395.

65. Diarra N, Klooster C, Togola A, Diallo D, Willcox M, Jong J. Ethnobotanical study of plants used against malaria in Sélingué subdistrict. Mali J Ethnopharmacol. 2015;166:352-360.

66. Abubakar MS, Musa AM, Ahmeda A, Hussaini IM. The perception and practice of traditional medicine in the treatment of cancers and inflammations by the Hausa and Fulani tribes of Northern Nigeria. J. Ethnopharmacol. 2007;111:625-629.

67. Fasola T, Ogunsola O. The proximate and phytochemical composition of Sesamum indicum Linn and Ceratotheca sesamoides Endl at different stages of growth. J Biol Agric Health. 2014;4:84-88.

68. Amujoyegbe OO, Idu M, Agbedahunsi JM, Erhabor JO. Ethnomedicinal Survey of medicinal plants used in the management of sickle cell disorder in Southern Nigeria. J Ethnopharmacol. 2015;85:347-360.

69. Olatunde O, Arinola GA. A vegetable, Launaea taraxacifolia, mitigated mercuric chloride alteration of the microanatomy of rat brain. J Dietary Supplements. 2017;4:613-625.

70. Obi RK, Umeh SC, Okurede OH, Iroagba II. Prevalence of Hepatitis B Virus among Pregnant Women attending an antenatal clinic in PortHarcourt, Nigeria. Afr J Clin Exp Microbiol. 2006;7:2-6.

71. Thomford NE, Mkhize B, Dzobo K, Mpye K, Rowe A, Parker MI, Wonkam A, Skelton M, September AV. Dandara C. African lettuce (Launaea taraxacifolia) displays possible anticancer effects and herb-drug interaction potential by CYP1A2, CYP2C9, and CYP2C19 Inhibition. OMICS A J Integr Biol. 2016;20:528-534.

72. Adinortey MB, Sarfo JK, Quayson ET, Weremfo A, Adinortey CA, Ekloh W, Ocran J. Phytochemical screening, proximate and mineral composition of Launaea taraxacifolia leaves. Res J Med Plant 2012;6:171-179.
73. Olugbenga DJ, Ukpanukpong, Undigweundeye R, Ngozi UR. Phytochemical Screening, proximate analysis and acute toxicity study of launaea taraxacifolia ethanolic extract on albino rats. Int J Sci Techn. 2015;3;199-202.

74. Gbadamosi IT, Okolosi O. Botanical galactogogues: nutritional values and therapeutic potentials. J Appl Biosci. 2013;61:4460-4469.

75. Olugbenga DJ, Undigweundeye UR, Ngozi UR. Phytochemical screening, proximate analysis and acute toxicity study of Launea taraxacifolia ethanolic extract on albino rats. Int J Sci Tech. 2015;3:199-202.

76. Koukoui O, Agbangnan P, Boucherie S, Yovo M, Nusse O, Combettes L, Sohounhloué D. Phytochemical study and evaluation of cytotoxicity, antioxidant and hypolipidemic properties of launaea taraxacifolia leaves extracts on cell lines HepG2 and PLB98. Am J Plant Sci. 2015;6:17681779.

77. Ruffina AN, Maureen CO, Esther AE, Chisom IF. Phytochemical analysis and antibacterial activity of launaea taraxacifolia ethanolic leave extract. Sch Acad J Biosci. 2016;4:193-196.

78. Soelberg J, Asase A, Akwetey, G, Jäger AK. Historical versus contemporary medicinal plant uses in Ghana. J Ethnopharmacol. 2015;160:109-132.

79. Bamishaiye El, Olayemi FF, Awagu EF, Bamishaiye MO. Proximate and phytochemical composition of Moringa oleifera leaves at three stages of maturation", Advance J Food Sci Technol. Vol. 3:233-237. Southern Nigeria. Int J Agri Food Sci. 2011;2:37-43.

80. Jimoh FO, Adedapo AA, Aliero AA, Koduru S, Afolayan AJ. Evaluation of the polyphenolic, nutritive and biological activities of the acetone, methanol and water extracts of Amaranthus asper. Open Complement Med J. 2010;2:7-14.

81. Adeniyi SA, Ehiagbonare JE, Nwangwu SCO. Nutritional evaluation of some staple leafy vegetables in Nigeria. Open Complement Med J. 2012;2:7-14.

82. Aloke C, Nachukwu N, Idenyi JN, Ugwuja El, Nwachi EU, Edeogu CO. Hypoglycaemic and hypolipidaemic effects of feed formulated with ceiba pentandra leaves in alloxan induced diabetic rats. Aust $\mathrm{J}$ Basic Appl Sci. 2010;4:4473-4477.

83. Anigo KMB, Dauda MD, Sallau AB, Chindo IE. Chemical composition of Kapok (Ceiba pentandra) seed and physicochemical properties of its oil. Nig J Basic Appl Sci. 2012;21:105-108.

84. Enechi DC, Ugwu KK, Ugwu OPC, Omeh YS. Evaluation of the antinutrient levels of Ceiba pentandra leaves. IJRRPAS. 2013;3:394-400. 